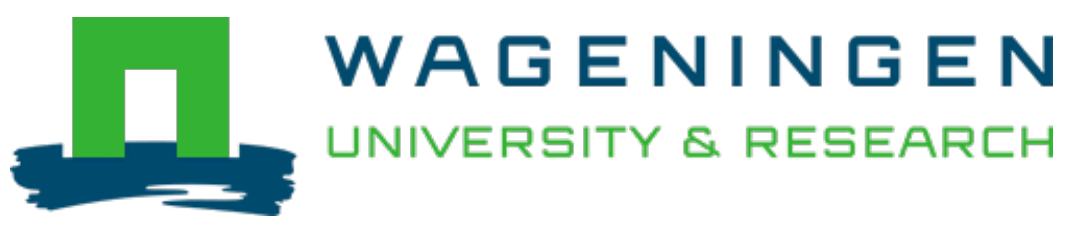

\title{
Effect of accelerated natural lactic fermentation of infant food ingredients on some pathogenic microorganisms
}

\author{
International Journal of Food Microbiology \\ Nout, M.J.R.; Rombouts, F.M.; Havelaar, A. \\ https://doi.org/10.1016/0168-1605(89)90006-8
}

This publication is made publicly available in the institutional repository of Wageningen University and Research, under the terms of article $25 \mathrm{fa}$ of the Dutch Copyright Act, also known as the Amendment Taverne. This has been done with explicit consent by the author.

Article 25 fa states that the author of a short scientific work funded either wholly or partially by Dutch public funds is entitled to make that work publicly available for no consideration following a reasonable period of time after the work was first published, provided that clear reference is made to the source of the first publication of the work.

This publication is distributed under The Association of Universities in the Netherlands (VSNU) 'Article $25 \mathrm{fa}$ implementation' project. In this project research outputs of researchers employed by Dutch Universities that comply with the legal requirements of Article $25 \mathrm{fa}$ of the Dutch Copyright Act are distributed online and free of cost or other barriers in institutional repositories. Research outputs are distributed six months after their first online publication in the original published version and with proper attribution to the source of the original publication.

You are permitted to download and use the publication for personal purposes. All rights remain with the author(s) and / or copyright owner(s) of this work. Any use of the publication or parts of it other than authorised under article $25 \mathrm{fa}$ of the Dutch Copyright act is prohibited. Wageningen University \& Research and the author(s) of this publication shall not be held responsible or liable for any damages resulting from your (re)use of this publication.

For questions regarding the public availability of this publication please contact openscience.library@wur.nl 


\title{
Effect of accelerated natural lactic fermentation of infant food ingredients on some pathogenic microorganisms
}

\author{
M.J.R. Nout ${ }^{1}$, F.M. Rombouts ${ }^{1}$ and A. Havelaar ${ }^{2}$ \\ ' Department of Food Science, Agricultural University, Wageningen, The Netherlands, and ${ }^{2}$ Laboratory \\ of Water and Food Microbiology, National Institute of Public Health and Environmental Protection, \\ Bilthoven, The Netherlands
}

(Received 2 January 1989; accepted 27 February 1989)

\begin{abstract}
Accelerated natural lactic fermentation in mixtures of water and ground sorghum, millet and pigeon pea was obtained by gradual selection of lactic acid bacteria, through inoculum recycling. Weaning food prepared from ingredients fermented this way, contained approx. $0.7 \%$ lactic and $0.05 \%$ acetic acids and had a $\mathrm{pH}$ of about 3.8. In porridges, a $\mathrm{pH}$ of $\leq 4.0$ was required to cause death of Salmonella typhimurium and Staphylococcus aureus. Several intestinal pathogenic bacteria were inoculated into sour porridge. The most resistant Salmonella sp. died at a rate of $1.2 \log$ cycle $/ \mathrm{h}$; the most resistant Shigella sp. at $0.9 \mathrm{log}$ cycle/h; and the most resistant Escherichia coli strain at $0.6 \log$ cycle $/ \mathrm{h}$. A yeast, Candida albicans, could grow well in the sour product, whereas a bacteriophage (MS-2) was inactivated at a rate of $0.1 \mathrm{log}$ cycle $/ \mathrm{h}$. In the acid-sensitive bacterial cultures, no gradual adaptation to acid environments could be observed. The survival studies were carried out at $30^{\circ} \mathrm{C}$.
\end{abstract}

Key words: Infant food; Weaning food; Lactic acid fermentation; Salmonella; Shigella; Escherichia coli; Pathogen; Diarrhea

\section{Introduction}

It has been estimated (Evans, 1986) that over 15 million infants and children below 5 years die annually in the tropical regions of the world. A major role in child mortality is played by combinations of diarrheal diseases, nutrient malabsorption and malnutrition. Based on 1980 data, it was estimated (Snyder and Merson, 1982) that acute diarrheal diseases accounted for approx. $10^{9}$ episodes and 4.6 million deaths of children aged under 5 years in the developing world.

In addition to bacterial intestinal pathogens causing infectious diarrhea, infantile gastroenteritis is associated with viral (e.g. Human RotaVirus) infections (Middleton et al., 1977). Also, parasitic infections (Itotia et al., 1978) may cause chronic or acute

Correspondence address: M.J.R. Nout, Department of Food Science, Agricultural University, Bomenweg 2, 6703 HD Wageningen, The Netherlands. 
diarrhea (Oyerinde et al., 1977; Oyerinde et al., 1979) or may contribute to malnutrition (Stephenson et al., 1980). Although the genera Salmonella, Campylobacter, Shigella, Vibrio, Yersinia and Escherichia are mostly associated (Snyder and Merson, 1982; Itotia et al., 1978; Agbonlahor and Odugbemi, 1982) with bacterial diarrheal disorders, other enterotoxigenic genera including Pseudomonas, Enterobacter, Klebsiella, Serratia, Proteus, Providencia, Aeromonas, Achromobacter and Flavobacterium have also been implied (Jiwa et al., 1981).

That food and food handlers play an important role as vectors for infective diarrhea has been demonstrated (Itotia et al., 1978; Jiwa et al., 1981; Rowland et al.. 1978).

Most weaning food is prepared by boiling the ingredients in water. Although the majority of microbial contaminants will be inactivated as a result, heat-resistant bacterial endospores may survive. Even more important, recontamination of the prepared weaning food is very likely to occur from utensils, handling, insects, faeces, etc. before it is consumed (Rowland et al., 1978). Whether this contamination pressure from the environment will lead to microbial growth and turn wholesome food into a health hazard, depends on: the nature of the contamination, the environment created by the food and the storage conditions.

Rowland et al. (1978) stressed that weaning foods for tropical use must be 'reasonably resistant to bacterial overgrowth for at least the 1-2 $\mathrm{h}$ when the infant is likely to be feeding'. The formulation of weaning foods according to the nutritional requirements of 9-12 months old children has been described elsewhere (Nout et al., 1989).

Recycling of inoculum achieves a natural selection of lactic acid bacteria (Nout et al., 1987b) in fermenting mixtures of cereals, tubers, legumes, and water (Nout et al., 1989). Acidification results in $\mathrm{pH} \leq 4.0$ within $8-10 \mathrm{~h}$ at $25-30^{\circ} \mathrm{C}$. If children's food (porridge) is prepared from such fermented material, a porridge $\mathrm{pH}$ of $\leq 4.0$ can be realized with most weaning food ingredients. The microbiological stability of acidified porridge has been mentioned earlier (Nout et al., 1989), using strains of Salmonella typhimurium and Staphylococcus aureus as test organisms. Antimicrobial influences in lactic fermented foods can be due to the production of various compounds, including organic acids, $\mathrm{H}_{2} \mathrm{O}_{2}$ and antibiotic-like substances (Gibbs, 1987). The present paper deals with the mechanism of the microbiological stability of fermented cereal porridge, and the behaviour of a number of pathogens responsible for gastroenteritis and closely related diseases.

\section{Materials and Methods}

\section{Ingredients}

Cereals and legumes used included white sorghum (Sorghum bicolor ssp. caffrorum) and Japanese millet (Echinodoa frumentacea); and pigeon pea (Cajanus cajan), respectively. Malt was prepared from white sorghum as described below. 


\section{Microbial cultures}

Candida albicans 240, Citrobacter 3465/69, Enterobacter cloacae, Escherichia coli strains $055,0111,0125$, and 0126, Salmonella abony KO 10, S. branderup No. 49, S. eastbourne, S. havana No. 134, S. senftenberg KO 36 (group E), S. typhi KO 120, S. typhimurium II 505 (resistant to $200 \mathrm{ppm}$ nalidixic acid), S. zanzibar No. 82, Shigella boydii 748, Sh. dysenteriae II ALM 59 (var. Schmitzii), Sh. flexneri II 850143, Sh. flexneri III 850161, Sh. sonnei 763, Staphylococcus aureus S6 (SEA, SEB), Yersinia enterocolitica P1272/11 6.30 + and phage MS-2 (F-specific RNA phage; host strain Salmonella typhimurium WG-49 phage-type $3 \mathrm{Nal}^{\mathrm{R}} \mathrm{F}^{\prime}$ lac: $\mathrm{Tn} 5$ ) were from the culture collection of the National Institute of Public Health and Environmental Protection, Bilthoven, The Netherlands. Citrobacter, Enterobacter, Escherichia, Salmonella except S. typhimurium, Shigella, Staphylococcus, and Yersinia were grown and maintained on slopes of Nutrient Agar (NA, Oxoid CM 3), and Candida on Malt Extract Agar (MEA, Oxoid CM59). S. typhimurium was grown and maintained in Brain Heart Infusion broth (BHI, Gibco, U.K., No. 152-0680) with $200 \mathrm{ppm}$ nalidixic acid (Sterling-Winthrop, Guildford, U.K.). Phage MS-2 was maintained at $-70^{\circ} \mathrm{C}$ in Tryptone Yeast Extract Glucose broth (TYG, prepared with trypticase peptone (BBL, 11921) $8 \mathrm{~g}$, Yeast Extract (Difco, 0127) $0.8 \mathrm{~g}, \mathrm{NaCl}$ (Merck, 6404) $6.4 \mathrm{~g}$ in $800 \mathrm{ml}$ distilled water, $\mathrm{pH} \mathrm{7.2,} \mathrm{sterilized} 15 \mathrm{~min}$ at $121^{\circ} \mathrm{C}$, followed by addition of $8 \mathrm{ml}$ of filter sterilized $(0.2 \mu \mathrm{m})$ solution of $\mathrm{CaCl}_{2} \cdot 2 \mathrm{H}_{2} \mathrm{O}$ (Merck, 2382) $3 \mathrm{~g}$, and glucose (Difco, 0155) $10 \mathrm{~g}$, in $100 \mathrm{ml}$ distilled water) to which $20 \%$ glycerol (Merck, 4094) was added.

\section{Preparation of ingredients}

Cereals and pigeon pea were cleaned dry and ground to whole-grain meals using a laboratory impact mill (Pallmann type REF L18, Zweibrücken, F.R.G.). Malt was prepared from white sorghum by subsequently soaking $6 \mathrm{~h}$ at $20^{\circ} \mathrm{C}$, discarding the water, aerating $15 \mathrm{~min}$, rinsing with fresh tapwater, soaking $18 \mathrm{~h}$ at $20^{\circ} \mathrm{C}$, discarding the water, rinsing the grain and spreading it $1 \mathrm{~cm}$ thick on a wet cloth, germinating 3 days at $20^{\circ} \mathrm{C}$ until root length reached $1.5 \mathrm{~cm}$, drying in a hot air oven at $50^{\circ} \mathrm{C}$ for $2 \mathrm{~h}$, removing rootlets by sieving and grinding the malted grain by impact milling.

\section{Composition of formulated porridges:}

We used two porridges, each designed to contain $4.20 \mathrm{~kJ}$ energy $/ \mathrm{ml}$ and a minimum of $7.8 \%$ net protein energy in order to cover the nutritional demands of children of the second semester (6-12 months). Formula 1 contained $23 \%$ ground Japanese millet, $4.3 \%$ ground pigeon pea, $1 \%$ ground sorghum malt, and $71.7 \%$ water. Formula 2 contained $22.8 \%$ ground white sorghum, $4.6 \%$ ground pigeon pea, $1 \%$ ground sorghum malt, and $71.6 \%$ water (percentages on weight basis). 


\section{Accelerated natural lactic fermentation}

The principle of gradual selection of lactic acid bacteria by recycling of inoculum was described earlier (Nout et al., 1987b). Mixtures of flour and tapwater (40:60, $\mathrm{w} / \mathrm{w}$ ) were incubated at $30^{\circ} \mathrm{C}$. Fermentation cycles were $24 \mathrm{~h}$. At the start of each new cycle, material of the previously fermented batch was added as a starter at an inoculum rate of $10 \%$. The fermented mixture is referred to as 'concentrate'.

\section{Preparation of porridge}

Using the above-mentioned formulas as a basis, an appropriate volume of tapwater was brought to a vigorous boil and a corresponding quantity of concentrate was added gradually while stirring to avoid lumps. After boiling $10 \mathrm{~min}$ at $100^{\circ} \mathrm{C}$, the viscous mass was allowed to cool to $45^{\circ}-55^{\circ} \mathrm{C}$; subsequently, the specified weight of malt was added and mixed by stirring. Liquefaction was allowed for $30 \mathrm{~min}$ and the product was boiled again $5 \mathrm{~min}$ to reduce the microbial load introduced by the malt, to inactivate the malt enzymes and to remove the gritty mouthfeel otherwise caused by the uncooked malt, and allowed to cool. The resulting final product is referred to as 'porridge'.

\section{Determination of death kinetics}

Batches of porridge were prepared as described above and distributed in $100 \mathrm{~g}$ portions in polyethylene bags which were heat-sealed and stored at $-20^{\circ} \mathrm{C}$ until use. After defrosting and warming up till $30^{\circ} \mathrm{C}$, porridges were inoculated with appropriate aliquots of BHI-cultures of the tested bacteria, Malt Extract broth (ME, Oxoid CM57) cultures of Candida, or phage MS-2 suspension in TYG broth. Subsequently, the inoculum was distributed through the porridge by mixing in a Colworth type 400 stomacher. Determination of viable cells or phages was carried out immediately after inoculation and after appropriate periods of incubation at $30^{\circ} \mathrm{C}$.

\section{Analysis}

Sampling: samples for chemical and microbiological analysis were $50 \mathrm{~g}$ and $10 \mathrm{~g}$, respectively. $p H$ : A pH meter (Electrofact, Sweden) with Schott N61 electrode was used. Titratable acidity: $10 \mathrm{~g}$ sample was mixed with $90 \mathrm{ml}$ distilled water and 0.1000 $\mathrm{M} \mathrm{NaOH}$ was added up to $\mathrm{pH} 8.50$, while stirring continuously. After $10 \mathrm{~min}$ stirring, more $\mathrm{NaOH}$ was added to adjust the $\mathrm{pH}$ to 8.50 , and this was repeated after another $10 \mathrm{~min}$ stirring. Acidity was reported as follows: $\mathrm{ml} \mathrm{NaOH} \times 10^{-3} \times$ $90=\%(\mathrm{w} / \mathrm{w})$ lactic acid. Organic acids: $\mathbf{L}(+)$-lactic acid and $\mathrm{D}(-)$-lactic acid were determined by enzyme assay (Cat. No. 139084, Boehringer, Mannheim, F.R.G.). Acetic acid was also determined by enzyme assay (Cat. No. 148261, Boehringer, Mannheim, F.R.G.). In addition, lactic and acetic acids were determined by HPLC (SpectraPhysics SP8000) after clarification with Carrez $\mathrm{A}\left(0.1 \mathrm{M} \mathrm{K}_{4} \mathrm{Fe}(\mathrm{CN})_{6} \cdot 3 \mathrm{H}_{2} \mathrm{O}\right)$ 
and $\mathrm{B}\left(0.2 \mathrm{M} \mathrm{ZnSO}_{4} \cdot 7 \mathrm{H}_{2} \mathrm{O}\right)$ solutions. Eluent used was $0.01 \mathrm{~N} \mathrm{H}_{2} \mathrm{SO}_{4}$ at $30^{\circ} \mathrm{C}$ and $80 \mathrm{bar}$, precolumn AG50W/X4 (BioRad), column HPX-87-H (BioRad), and detector RI2 $\times$ shodex RI SE-61.

Microbiological analysis: Sample preparation and determinations of total aerobic count, yeasts and lactic acid bacteria were as described earlier (Nout et al., 1987a). In all enumerations of Enterobacteriaceae, resuscitation on solid medium was carried out by spreading $0.1 \mathrm{ml}$ of appropriate sample dilution on thin Tryptone Soya Agar (TSA, Oxoid CM 131) plates and incubating $2 \mathrm{~h}$ at $37^{\circ} \mathrm{C}$. Subsequently, a thick overlay of Violet Red Bile Glucose (VRBG, Oxoid CM485) agar was applied followed by incubation for $24 \mathrm{~h}$ at $37^{\circ} \mathrm{C}$. Enumeration of the nalidixic acid resistant strain of Salmonella typhimurium was carried out in pour plates of Plate Count Agar (PCA, Oxoid CM 325) containing $200 \mathrm{ppm}$ nalidixic acid at $37^{\circ} \mathrm{C}$ for $24 \mathrm{~h}$. If sublethal injury was expected, resuscitation was carried out by spreading $0.1 \mathrm{ml}$ diluted sample on thin Tryptone Soya Agar plates (TSA, Oxoid CM 131) and incubating $2 \mathrm{~h}$ at $37^{\circ} \mathrm{C}$. Subsequently, a thick overlay of PCA $+200 \mathrm{ppm}$ nalidixic acid and incubation at $37^{\circ} \mathrm{C}$ for $24 \mathrm{~h}$ was applied. If numbers of $S$. typhimurium were below the detection level of the pour plates with PCA, a qualitative method was used to detect the presence or absence of viable cells. In that case, pre-enrichment from $25 \mathrm{~g}$ sample in $225 \mathrm{ml}$ Buffered Peptone Water (BPW, Oxoid CM 509) for $20 \mathrm{~h}$ at $37^{\circ} \mathrm{C}$ was followed by selective enrichment of $0.1 \mathrm{ml}$ BPW culture in 100 $\mathrm{ml}$ Rappaport Vassiliadis medium (RV, Oxoid CM 669) with $150 \mathrm{ppm}$ nalidixic acid for $48 \mathrm{~h}$ at $42.5^{\circ} \mathrm{C}$ and surface streaking of plates of Brilliant Green Agar (BGA, Oxoid CM 329) after $24 \mathrm{~h}$ and $48 \mathrm{~h}$. BGA was incubated for $24 \mathrm{~h}$ at $37^{\circ} \mathrm{C}$. Enumeration of Staphylococcus aureus using Baird-Parker medium was carried out as reported elsewhere (Nout et al., 1988). Plaque-forming units of phage MS-2 were determined after $18 \mathrm{~h}$ incubation at $37^{\circ} \mathrm{C}$ of Tryptone Yeast Extract $2 \%$ Agar (TYG with $2 \%$ agar (Sobigel)) plates, with an overlay consisting of a mixture of 2.5 $\mathrm{ml}$ Tryptone Yeast Extract Glucose 1\% Agar (TYG with 1\% agar (Sobigel)), $1 \mathrm{ml}$ host suspension containing $1-3 \cdot 10^{8} / \mathrm{ml}$ Salmonella typhimurium WG-49 in TYG broth, and $1 \mathrm{ml}$ of sample dilution. Reporting of counts and detection limits were described earlier (Nout et al., 1987a).

\section{Results and Discussion}

The simple method of recycling inoculum has long been known and is still used at present in, for example, the maintenance of sourdough. The establishment of a stable microflora in sourdough through natural selection is well documented (Sugihara, 1985). Recently, we found (Nout et al., 1987b) that this recycling technique can be employed successfully to enhance the pre-fermentation of soyabeans for tempe manufacture, resulting in improved bacteriological safety and acceptability of tempe. Table I summarizes the changes in microbiological composition and acidity when the recycling inoculum method is applied to the fermentation of a mixture of sorghum and pigeon pea meals in water. Compared with a spontaneous fermentation occurring during overnight incubation (Table I, situation 


\section{TABLE I}

Fermentation of sorghum/pigeon pea porridge base (33.3\% sorghum, $6.7 \%$ pigeon pea, $60.0 \%$ water), by recycling of inoculum (incubation at $30^{\circ} \mathrm{C}$, cycles of $24 \mathrm{~h}$, inoculum rate $10 \%$ )

\begin{tabular}{lllllc}
\hline $\begin{array}{l}\text { Fermentation } \\
\text { cycle }\end{array}$ & $\mathrm{pH}$ & $\begin{array}{l}\text { Total aerobic } \\
\text { bacteria }\end{array}$ & $\begin{array}{l}\text { Lactic acid } \\
\text { bacteria }\end{array}$ & Yeasts & Enterobacteriaceae \\
\hline $0^{\mathrm{a}}$ & 6.3 & $5.95^{\mathrm{c}}$ & 4.67 & 3.65 & 4.15 \\
$1^{\mathrm{h}}$ & 4.8 & 9.69 & 9.61 & 7.17 & 5.98 \\
$2^{\mathrm{b}}$ & 3.9 & 9.24 & 9.18 & 5.74 & $<2.70$ \\
3 & 3.9 & 9.34 & 9.31 & 6.51 & $<2.70$ \\
4 & 3.8 & 9.47 & 9.41 & 7.84 & $<2.70$ \\
5 & 3.7 & 9.67 & 9.61 & 7.23 & $<2.70$ \\
6 & 3.7 & 9.15 & 9.61 & 6.78 & $<2.70$ \\
\hline
\end{tabular}

a Measured at the start of the first cycle.

b Measured at the end of cycle $1,2,3$, etc.

c Counts expressed as ${ }^{10} \log \mathrm{N} / \mathrm{g}$ porridge base.

at the end of the first cycle), repeated recycling of inoculum results in an accelerated acidification of inoculated fresh batches after $2-4$ recyclings. Due to the dominance of lactic acid bacteria and rapid acidification, Enterobacteriaceae are absent in the fermented material, even though they are introduced with each new batch of cereal and legume meal.

To determine the effect of the extent of fermentation on the microbiological stability of weaning food, porridge was prepared from different ratios of fermented and non-fermented ingredients. Table II shows that Salmonella typhimurium and

TABLE II

Influence of initial $\mathrm{pH}$ of millet/pigeon pea (formula 1) on microbiological stability in challenge tests with Salmonella typhimurium and Staphylococcus aureus at $30^{\circ} \mathrm{C}$

\begin{tabular}{|c|c|c|c|c|c|}
\hline $\begin{array}{l}\text { Ratio } \mathrm{F} / \mathrm{NF}^{\mathrm{a}} \text { : } \\
\text { Initial } \mathrm{pH}^{\mathrm{b}} \text { : }\end{array}$ & $\begin{array}{l}0 / 100 \\
6.00^{\circ}\end{array}$ & $\begin{array}{l}40 / 60 \\
5.08\end{array}$ & $\begin{array}{l}60 / 40 \\
4.16\end{array}$ & $\begin{array}{l}80 / 20 \\
3.96\end{array}$ & $\begin{array}{l}100 / 0 \\
3.82\end{array}$ \\
\hline \multicolumn{6}{|l|}{ S. typhimurium } \\
\hline$t_{0}($ initial $)$ & 4.44 & 4.92 & 4.44 & 4.74 & 4.44 \\
\hline$t_{10 \mathrm{~h}}$ & 7.70 & 5.39 & 3.77 & $<2.4+^{\mathrm{d}}$ & $<2.4+$ \\
\hline$t_{24 \mathrm{~h}}$ & 8.06 & 7.52 & $<2.4+$ & $-d$ & - \\
\hline$t_{48 \mathrm{~h}}$ & 8.10 & 7.50 & - & - & - \\
\hline \multicolumn{6}{|l|}{ S. aureus } \\
\hline$t_{0}$ (initial) & 4.44 & 4.44 & 4.44 & 4.44 & 4.44 \\
\hline$t_{10 \mathrm{~h}}$ & 7.22 & 6.04 & 3.59 & 2.44 & $<2.4$ \\
\hline$t_{24 \mathrm{~h}}$ & 8.53 & 7.96 & $<2.4$ & $<2.4$ & $<2.4$ \\
\hline
\end{tabular}

a $\mathrm{F} / \mathrm{NF}=$ fermented/non-fermented millet/pigeon pea base.

${ }^{b}$ Obtained by cooking porridge from different mixing ratios of fermented $(\mathrm{pH} 3.82)$ and non-fermented (pH 6.00) concentrates.

c Counts expressed as ${ }^{10} \log \mathrm{N} / \mathrm{g}$ porridge.

$\mathrm{d}+$ presence still detectable by liquid selective enrichment, - absent by liquid selective enrichment. 
TABLE III

Effect of non-fermentative and fermentative acidification and dehydration on antimicrobial properties of sorghum/pigeon pea (formula 2 ) at $30^{\circ} \mathrm{C}$

\begin{tabular}{|c|c|c|c|}
\hline \multirow[t]{2}{*}{${ }^{10} \log N / g$ porridge } & \multirow{2}{*}{$\begin{array}{l}\text { Non-fermented } \\
\text { with added acids } \\
\text { (fresh) }\end{array}$} & \multicolumn{2}{|c|}{ Fermented } \\
\hline & & $\overline{\text { Fresh }}$ & $\begin{array}{l}\text { Dehydrated } \\
\text { reconstituted }\end{array}$ \\
\hline \multicolumn{4}{|c|}{ Salmonella typhimurium II 505} \\
\hline$t_{0}$ & 7.00 & 7.24 & 7.15 \\
\hline$t_{3 \mathrm{~h}}$ & 3.59 & 3.04 & 2.80 \\
\hline$t_{6 \mathrm{~h}}$ & 3.00 & $<2.70$ & $<2.70$ \\
\hline$t_{24 \mathrm{~h}}$ & $<2.70$ & $<2.70$ & $<2.70$ \\
\hline \multicolumn{4}{|c|}{ Yersinia enterocolitica $\mathbf{P} 1272 / 116.30+$} \\
\hline$t_{0}$ & 7.32 & 7.19 & 7.26 \\
\hline$t_{3 \mathrm{~h}}$ & 3.30 & 4.74 & $<2.70$ \\
\hline$t_{6 \mathrm{~h}}$ & $<2.70$ & $<2.70$ & $<2.70$ \\
\hline \multicolumn{4}{|l|}{ Escherichia coli } \\
\hline$t_{0}$ & 7.34 & 7.26 & 7.15 \\
\hline $\mathrm{t}_{2.5 \mathrm{~h}}$ & 6.86 & 7.04 & 7.09 \\
\hline$t_{5 \mathrm{~h}}$ & 6.26 & 6.35 & 6.69 \\
\hline$t_{7 \mathrm{~h}}$ & 4.59 & 4.57 & 4.34 \\
\hline$t_{24 \mathrm{~h}}$ & $<2.70$ & $<2.70$ & $<2.70$ \\
\hline \multicolumn{4}{|l|}{ Citrobacter $3465 / 69$} \\
\hline$t_{0}$ & 7.03 & 7.15 & 6.18 \\
\hline$t_{3 \mathrm{~h}}$ & 3.33 & $<2.70$ & 2.81 \\
\hline$t_{6 \mathrm{~h}}$ & $<2.70$ & $<2.70$ & $<2.70$ \\
\hline \multicolumn{4}{|l|}{ Enterobacter cloacae } \\
\hline$t_{0}$ & 7.18 & 7.10 & 7.18 \\
\hline$t_{3 \mathrm{~h}}$ & $<2.70$ & $<2.70$ & 2.78 \\
\hline
\end{tabular}

Staphylococcus aureus could grow very well in porridges of pH 6.00 made with $100 \%$ non-fermented ingredients, as could be expected. The higher the proportion of fermented ingredient base, the lower was the porridge $\mathrm{pH}$ after preparation. At $\mathrm{pH} \leq 4.16$, porridges caused a reduction of inoculated salmonellae and staphylococci. The highest anti-microbial activity was found in porridges of $\mathrm{pH} \leq 3.96$. These $\mathrm{pH}$ levels could only be obtained using the system of accelerated natural lactic fermentation (Table I).

We investigated whether anti-microbial effects other than acidity were present in the fermented ingredients by simulating the conditions of the fermented material in non-fermented ingredients by the addition of $0.7 \%(\mathrm{w} / \mathrm{w})$ lactic and $0.05 \%(\mathrm{w} / \mathrm{w})$ acetic acids and adjustment of the $\mathrm{pH}$ to 3.80 corresponding to the results obtained by analysis of the fermented ingredients. Table III shows the effect of acidity in sorghum/pigeon pea porridges on selected bacterial cultures. There appeared to be no significant difference between their behaviour in fermented porridge or acid-supplemented non-fermented porridge, which implies that the anti-microbial effect is 


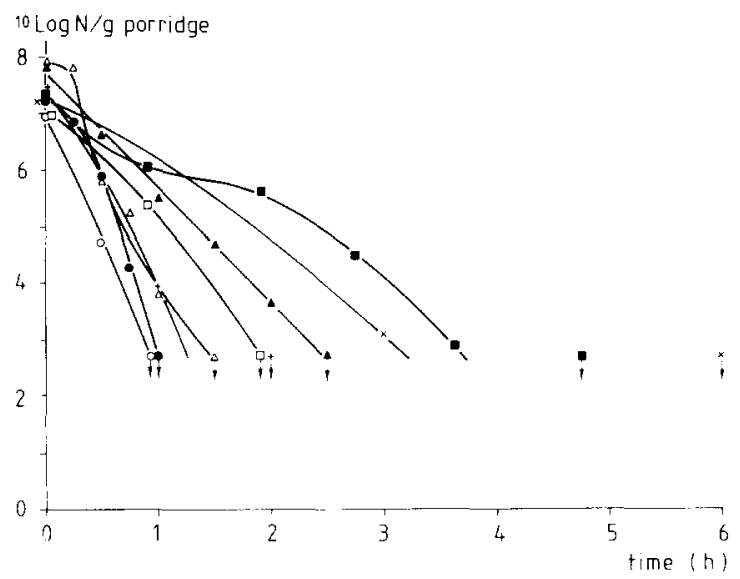

Fig. 1. Death kinetics of Salmonella strains inoculated into porridge (formula 2, $\mathrm{pH} 3.80$ ) made from fermented sorghum/pigeon pea and incubated at $30^{\circ} \mathrm{C}$. Salmonella abony - Salmonella branderup $\bigcirc-0$, Salmonella eastbourne ^- , Salmonella havana $\triangle-\triangle$, Salmonella

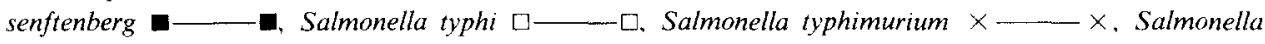
zanzibar $+\longrightarrow+$

due to the presence of lactic and acetic acids at reduced $\mathrm{pH}$, and that other anti-microbial substances did not play a detectable role.

Cooked fermented porridge was dehydrated by drum-drying and reconstituted with tapwater at $30^{\circ} \mathrm{C}$ to the original porridge dry matter content. No significant influence of this treatment on the death rate of the inoculated bacteria was observed, which indicates that losses of organic acids due to evaporation during drum-drying are negligible. Since some loss of volatile fatty acids, e.g. acetic acid had been expected, chemical analysis of organic acids in fresh and drum-dried porridge was carried out by HPLC. It was confirmed that there are no significant losses of organic (i.e. lactic and acetic) acids resulting from the drum-drying process (data not included).

Figs. 1-3 show the destruction curves in sorghum/pigeon pea porridge $(\mathrm{pH} 3.80)$ at $30^{\circ} \mathrm{C}$ of a number of bacteria associated with acute diarrhea. In Fig. 1, Salmonella species are shown to vary with respect to death rate and shape of the death curve. The most resistant strain, $S$. senftenberg, died at a rate of approx. 1.2 $\log$ cycle/h. Fig. 2 illustrates the behaviour of some Shigella strains. Except for the sensitive $S h$. dysenteriae strain, the other shigellas had a death-curve with a slow on-set followed by a higher death rate. The most resistant strains died at an average rate of $0.9 \mathrm{log}$ cycle/h. In Fig. 3, strains of Citrobacter, Escherichia coli and Yersinia enterocolitica are shown. E. coli strains 055 and 0111 were most resistant (average rate of death of strain 0111 was $0.6 \log$ cycle $/ \mathrm{h}$ ) and showed curves similar to the Shigella strains.

Fig. 4 shows that the tested yeast Candida albicans was perfectly able to grow at $30^{\circ} \mathrm{C}$ in the sour porridge, as would be expected. The same figure also illustrates the fate of bacteriophage MS- 2 in the fermented porridge, as well as in a neutral, 


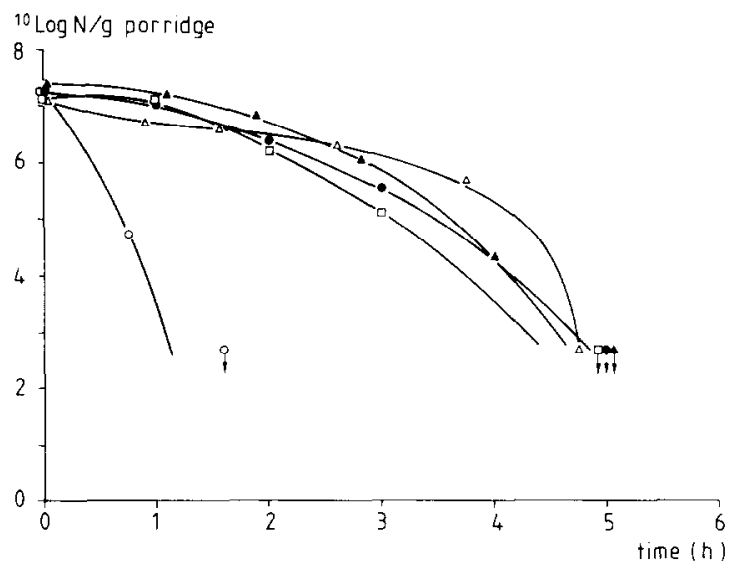

Fig. 2. Death kinetics of Shigella strains inoculated into porridge (formula 2, pH 3.80) made from fermented sorghum/pigeon pea and incubated at $30^{\circ} \mathrm{C}$. Shigella boydii $-\bullet$, Shigella dysenteriae

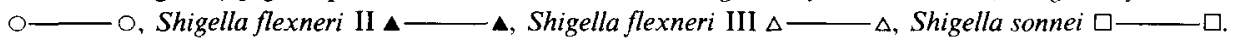

non-fermented control porridge. The acid conditions resulted in a (slow) inactivation rate of approx. $0.1 \mathrm{log}$ cycle/h. Although it is not known whether the behaviour of this phage is representative for other viruses, this result indicates a slight viricidal activity of fermented porridge. It should be realized that several viruses (e.g. the enteroviruses) are less sensitive to low $\mathrm{pH}$.

All bacteria died rather quickly in the sour porridge. With E. coli 0125, E. coli 0126 and Shigella flexneri II we investigated whether a gradual adaptation to the

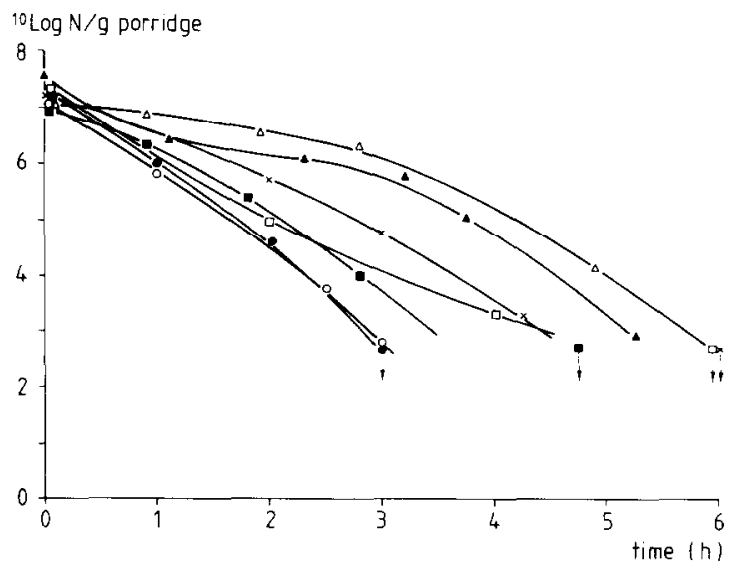

Fig. 3. Death kinetics of Citrobacter, Enterobacter cloacae, Escherichia coli and Yersinia enterocolitica inoculated into porridge (formula 2, $\mathrm{pH} 3.80$ ) made from fermented sorghum/pigeon pea and incubated at $30^{\circ} \mathrm{C}$. Citrobacter Escherichia coli 0111

- Enterobacter cloacae

$\Delta$, Escherichia coli 0125

- O, Escherichia coli 055

Yersinia enterocolitica

- , Escherichia coli 0126

$\Delta-\mathbf{\Delta}$

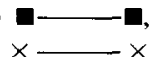




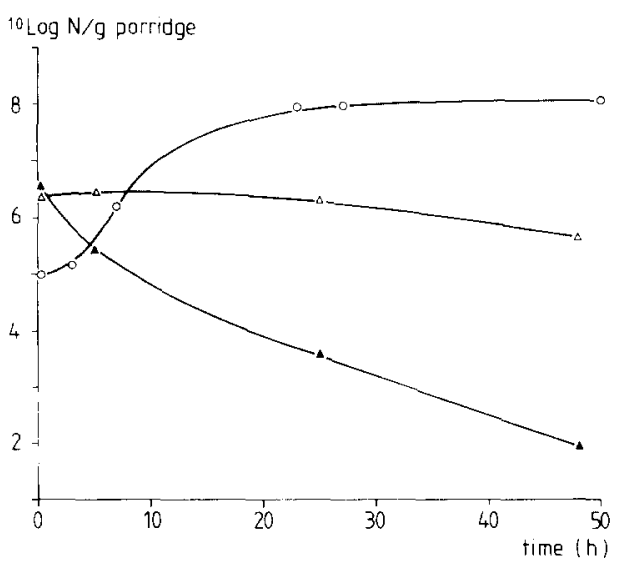

Fig. 4. Fate of Candida albicans and phage MS-2 inoculated into porridge (formula 2, pH 3.80) made from fermented sorghum/pigeon pea and incubated at $30^{\circ} \mathrm{C}$. Candida albicans $\bigcirc-0$, Phage MS-2

$\triangle \longrightarrow$. Phage MS-2 in control ( $\mathrm{pH} 6.00$ ) porridge $\Delta-\triangle$.

acid conditions could be achieved. This was done by culturing the tested strains in successive porridges in which increasing proportions of fermented ingredients were used. Since the strains died in porridges of $\mathrm{pH} \leq 4.0$ at repeated attempts (data not included), we concluded that there is little risk of the development of acid-resistant adaptations. Our results show that porridges of $\mathrm{pH} \leq 4.0$ made with lactic fermented ingredients have significant antimicrobial properties through which they might contribute to the reduction of the foodborne infection pressure at the household level.

\section{Acknowledgement}

Cooperation from the following is gratefully acknowledged: G. Stoffels, M. Lodema and T. Roos, Department of Food Science, Agricultural University, for technical contributions; Grano Drente, Meeuwen, for cereals and legumes provided: R. Pot-Hogeboom and S. Notermans, National Institute of Public Health and Environmental Protection, Bilthoven, for virological assistance and bacterial cultures provided.

\section{References}

Agbonlahor, D.E. and Odugbemi, T.O. (1982) Enteropathogenic, enterotoxigenic and enteroinvasive Escherichia coli isolated from acute gastroenteritis patients in Lagos, Nigeria, Trans. R. Soc. Trop. Med. Hyg. 76, 265-267.

Evans, J.R. (1986) International health: a rationale. Am. Soc. Microbiol. News 52, 460-464.

Gibbs, P.A. (1987) Novel uses for lactic acid fermentation in food preservation. J. Appl. Bacteriol. Symposium Suppl. 16, 51S-58S. 
Itotia, J.N., Cruickshank, B. and Refai, M. (1978) Bacteriological and parasitological investigations on faeces from diarrhoeal cases and apparently healthy persons with reference to food handlers in Kenya. East Afr. Med. J. 55, 366-372.

Jiwa, S.F.H., Krovacek, K. and Wadström, T. (1981) Enterotoxigenic bacteria in food and water from an Ethiopian community. Appl. Environ. Microbiol. 41, 1010-1019.

Middleton, P.J., Szymanski, M.T. and Petric, M. (1977) Viruses associated with acute gastroenteritis in young children. Am. J. Dis. Child. 131, 733-737.

Nout, M.J.R., Beernink, G. and Bonants-van Laarhoven, T.M.G. (1987a) Growth of Bacillus cereus in soyabean tempeh. Int. J. Food Microbiol, 4, 293-301.

Nout, M.J.R., de Dreu, M.A., Zuurbier, A.M. and Bonants-van Laarhoven, T.M.G. (1987b) Ecology of controlled soyabean acidification for tempe manufacture. Food Microbiol. 4, 165-172.

Nout, M.J.R., Notermans, S. and Rombouts, F.M. (1988) Effect of environmental conditions during soya-bean fermentation on the growth of Staphylococcus aureus and production and thermal stability of enterotoxins A and B. Int. J. Food Microbiol. 8, 299-309.

Nout, M.J.R., Rombouts, F.M. and Hautvast, G.J.A.J. (1989) Accelerated natural lactic fermentation of infant food formulations. UNU Food and Nutrition Bulletin.

Oyerinde, J.P.O., Ogunbi, O. and Alonge, A.A. (1977) Age and sex distribution of infections with Entamoeba histolytica and Giardia intestinalis in the Lagos population. Int. J. Epidemiol. 6, 231-234.

Oyerinde, J.P.O., Alonge, A.A., Adegbite-Hollist, A.F. and Ogunbi, O. (1979) The epidemiology of Entamoeba histolytica in a Nigerian urban population. Int. J. Epidemiol. 8, 55-59.

Rowland, M.G.M., Barrell, R.A.E. and Whitehead, R.G. (1978) Bacterial contamination in traditional Gambian weaning foods. Lancet. January 21, p. 136-138.

Snyder, J.D. and Merson, M.H. (1982) The magnitude of the global problem of acute diarrhoeal disease: a review of active surveillance data. Bull. WHO 60, 605-613.

Stephenson, L.S., Crompton, D.W.T., Latham, M.C., Schulpen, T.W.J., Nesheim, M.C. and Jansen, A.A.J. (1980) Relationships between Ascaris infection and growth of malnourished pre-school children in Kenya. Am. J. Clin. Nutr. 33, 1165-1172.

Sugihara, T.F. (1985) Microbiology of breadmaking. In: B.J.B. Wood (Ed.), Microbiology of Fermented Foods, Vol. 1, Elsevier Applied Sci., Barking, pp. 249-261. 